University of South Carolina

Scholar Commons

Faculty Publications

Earth, Ocean and Environment, School of the

4-2011

\title{
Two-Stepping into the Icehouse: East Antarctic Weathering During Progressive Ice-Sheet Expansion at the Eocene-Oligocene Transition
}

\author{
Howie Scher \\ University of South Carolina - Columbia, hscher@geol.sc.edu \\ Steven M. Bohaty \\ University of California - Santa Cruz \\ James C. Zachos

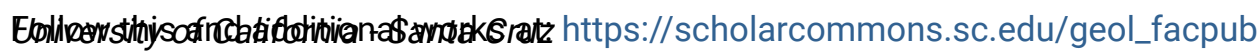 \\ ividgarteff the Eeratheyciences Commons \\ University of California - Santa Cruz
}

\section{Publication Info}

Published in Geology, Volume 39, Issue 4, 2011, pages 383-386.

Scher, H. D., Bohaty, S. M., Zachos, J. C., \& Delaney M. L. (2011). Two-stepping into the icehouse: East Antarctic weathering duringprogressive ice-sheet expansion at the Eocene-Oligocene transition. Geology, 39 (4), 383-386.

(C) Geology 2011, Geological Society of America

Copyright not claimed on content prepared wholly by U.S. government employees within scope of their employment. Individual scientists are hereby granted permission, without fees or further requests to GSA, to use a single figure, a single table, and/or a brief paragraph of text in subsequent works and to make unlimited copies of items in GSA's journals for noncommercial use in classrooms to further education and science. This file may not be posted to any Web site, but authors may post the abstracts only of their articles on their own or their organization's Web site providing the posting includes a reference to the article's full citation. GSA provides this and other forums for the presentation of diverse opinions and positions by scientists worldwide, regardless of their race, citizenship, gender, religion, or political viewpoint. Opinions presented in this publication do not reflect official opinions of the Society.

This Article is brought to you by the Earth, Ocean and Environment, School of the at Scholar Commons. It has been accepted for inclusion in Faculty Publications by an authorized administrator of Scholar Commons. For more information, please contact digres@mailbox.sc.edu. 


\author{
Howie D. Scher ${ }^{1 *}$, Steven M. Bohaty²†, James C. Zachos², and Margaret L. Delaney ${ }^{1}$ \\ ${ }^{1}$ Ocean Sciences Department, and Institute of Marine Sciences, University of California-Santa Cruz, Santa Cruz, California 95064, USA \\ 'Earth and Planetary Sciences Department, and Institute of Marine Sciences, University of California-Santa Cruz, Santa Cruz, \\ California 95064, USA
}

\begin{abstract}
In conjunction with increasing benthic foraminiferal $\delta^{18} \mathrm{O}$ values at the Eocene-Oligocene transition (EOT; ca. $34 \mathrm{Ma}$ ), coarse-grained ice-rafted debris (IRD; >425 $\mu \mathrm{m}$ ) appears abruptly alongside fossil fish teeth with continentally derived neodymium (Nd) isotope ratios $\left(\varepsilon_{\mathrm{Nd}}\right)$ in Kerguelen Plateau (Southern Ocean) sediments. Increased Antarctic weathering flux, as inferred from two steps to less radiogenic $\varepsilon_{\mathrm{Nd}}$ values, coincides with two steps in benthic foraminiferal $\delta^{18} \mathrm{O}$ values. These results indicate that two distinct surges of weathering were generated by East Antarctic ice growth during the EOT. Weathering by ice sheets during a precursor glaciation at 33.9 Ma did not produce significant IRD accumulation during the first $\varepsilon_{\mathrm{Nd}}$ shift. Glacial weathering was sustained during a terrace interval between the two steps, probably by small high-elevation ice sheets. A large increase in weathering signals the rapid coalescence of small ice sheets into an ice sheet of continental proportions ca. 33.7 Ma. Rapid ice sheet expansion resulted in a suppression of weathering due to less exposed area and colder conditions. Parallel changes in Antarctic weathering flux and deep-sea carbonate accumulation suggest that ice-sheet expansion during the EOT had a direct impact on the global carbon cycle; possible mechanisms include associated changes in silicate weathering on the East Antarctic craton and enhanced fertilization of Southern Ocean waters, both of which warrant further investigation.
\end{abstract}

\section{INTRODUCTION}

The sudden appearance of ice sheets on Antarctica during the Eocene-Oligocene transition (EOT) produced a surge of erosion that carried weathering products to depocenters around the circum-Antarctic. Remnants of this weathering event are found in Early Oligocene strata as glaciomarine sequences on the continental shelves (Cooper and O'Brien, 2004) and as coarse grains of ice-rafted debris (IRD) in pelagic sediments (Zachos et al., 1992). A shift from smectite- to illite-dominated clay mineral assemblages signals the transition from a chemical weathering regime on Antarctica to one of mechanical weathering by ice sheets (Ehrmann and Mackensen, 1992). However, knowledge of the timing and magnitude of weathering and IRD deposition in the Early Oligocene is limited compared to cooling and/or ice volume increase history gleaned from deep-sea benthic foraminiferal $\delta^{18} \mathrm{O}$ records, which reveal a two-step transition from greenhouse to icehouse climate (Coxall et al., 2005).

Radiogenic isotopes of long-lived radioactive systems are excellent paleoceanographic proxies for continental weathering (e.g., Arm-

*Current address: Department of Earth and Ocean Sciences, University of South Carolina, Columbia, South Carolina 29208, USA; E-mail: hscher@geol .sc.edu.

${ }^{\dagger}$ Current address: School of Ocean and Earth Science, University of Southampton, National Oceanography Centre, Southampton SO14 3ZH, UK. strong, 1971) because of the great isotopic disparity between mantle-derived and continental sources (e.g., Zachos et al., 1999; Dalai et al., 2006). Seawater neodymium (Nd) is almost exclusively derived from continental weathering (e.g., van de Flierdt et al., 2007) and has a short residence time (500-1000 yr) compared to the duration of the EOT ( 200 k.y.). Fossil fish teeth in pelagic sediments take up large amounts of Nd during early diagenesis (Bernat, 1975) Rates of postburial Nd uptake (e.g., Kocsis et al., 2010) are very low relative to early diagenetic rare earth element (REE) uptake in oxidizing pelagic sediments (e.g., Staudigel et al., 1985; C. Trueman, 2010, personal commun.), permitting retention of bottom-water $\varepsilon_{\mathrm{Nd}}$ values (e.g., Martin and Haley, 2000). Thus, changes in fossil fish tooth $\varepsilon_{\mathrm{Nd}}$ records from sediment cores near Antarctica are likely to preserve a signal of $\mathrm{Nd}$ carried with the weathering surge in the EOT interval. The objectives of this study are to determine the signal of Antarctic weathering and evaluate the timing of weathering changes relative to IRD deposition and cooling and ice volume proxies across the EOT. relative to bulk Earth, where $\varepsilon_{\mathrm{Nd}}$ values of continental crust become less radiogenic (i.e., negative) with older mantle extraction ages (DePaolo and Wasserburg, 1976). Low-resolution Nd isotope records reveal anomalously low $\varepsilon_{\mathrm{Nd}}$ values for Southern Ocean waters at $34 \mathrm{Ma}$ (Scher and Martin, 2004, 2006), indicating a source of non-
The $\varepsilon_{\mathrm{Nd}}$ values reflect the ${ }^{143} \mathrm{Nd} /{ }^{144} \mathrm{Nd}$ ratio radiogenic $\mathrm{Nd}$ (i.e., typical of ancient continental crust). Low $\varepsilon_{\mathrm{Nd}}$ values at the EOT could be a signal of Antarctic glacial weathering (Scher and Martin, 2004). Precambrian basement, including Archean terranes in Prydz Bay (Fitzsimons, 2003), outcrops in East Antarctica (Fig. 1A), contributing sediment with extremely nonradiogenic Nd to Prydz Bay and areas around the Kerguelen Plateau (Fig. 1B; Roy et al., 2007; van de Flierdt et al., 2007). These terranes are the likely source of low $\varepsilon_{\mathrm{Nd}}$ values measured in Late Eocene glaciomarine sediments within Prydz Bay (van de Flierdt et al., 2008).

\section{MATERIAL AND METHODS}

We developed coupled records of benthic foraminiferal $\delta^{18} \mathrm{O}$, fossil fish tooth $\varepsilon_{\mathrm{Nd}}$, and IRD concentrations from the EOT interval of Ocean
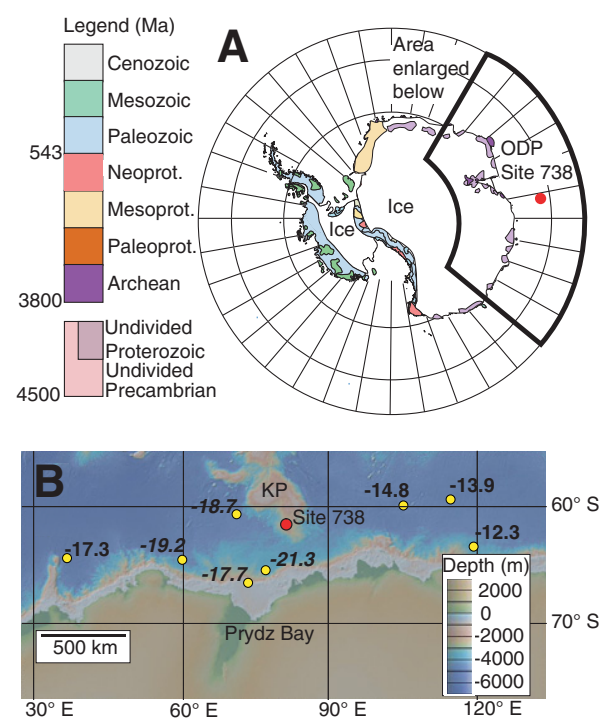

Figure 1. A: Antarctic outcrops with colors corresponding to geological age (prot.Proterozoic), modified from Roy et al. (2007), and position of Ocean Drilling Program (ODP) Site 738 (red dot; 62 $43^{\prime} \mathrm{S}, 8^{\circ} 47^{\prime} \mathrm{E}$, $2253 \mathrm{~m}$ water depth, $1750 \mathrm{~m}$ EOT [EoceneOligocene transition] paleodepth). B: Detrital $\varepsilon_{\mathrm{Nd}}$ values from circum-Antarctic core-top samples (yellow dots) (Roy et al., 2007; van de Flierdt et al., 2007) and study site (red dot). The least radiogenic $\varepsilon_{\mathrm{Nd}}$ values (i.e., lowest) in the circum-Antarctic are found in the Prydz Bay sector; they average $-21 \varepsilon_{\mathrm{Nd}}$ (average of values in italics) and reflect ancient sediment sources in East Antarctica and within Prydz Bay (shown in A). 
Drilling Program (ODP) Site 738 (Fig. 2). ODP Hole $738 \mathrm{~B}$ was sampled at an average interval of $11 \mathrm{~cm}$ between $\sim 18.0$ and $29.5 \mathrm{~m}$ below seafloor (total 99 samples), spanning the interval between 34.1 and 33.4 Ma on our age model. Details for analytical methods and the age model are given in the GSA Data Repository. ${ }^{1}$

\section{RESULTS}

The $\delta^{18} \mathrm{O}$ record for Site 738 derived from the benthic foraminifera Cibicidoides praemundulus reveals a two-step pattern (Fig. 2, left panel), similar to that found by Coxall et al. (2005) at ODP Site 1218 in the equatorial Pacific. The first step occurs ca. 33.9 Ma and the second, larger, step occurs ca. 33.7 Ma. An interval of intermediate and relatively uniform $\delta^{18} \mathrm{O}$ values produces a terrace between the two prominent steps (33.9-33.7 Ma).

The primary feature of the fossil fish tooth $\mathrm{Nd}$ isotope record is a two-stage excursion to less radiogenic $\varepsilon_{\mathrm{Nd}}$ values (Fig. 2, center). During the preexcursion interval (34.5-33.9 Ma), $\varepsilon_{\mathrm{Nd}}$ values average -7.3 . The excursion interval (33.9-33.6 Ma) begins with a step decrease of $0.7 \varepsilon_{\mathrm{Nd}}$ that coincides with the first $\delta^{18} \mathrm{O}$ step. The first $\mathrm{Nd}$ isotope step is followed by an $\sim 150$ k.y. interval of uniform $\varepsilon_{\mathrm{Nd}}$ values, similar to the $\delta^{18} \mathrm{O}$ terrace interval. The $\varepsilon_{\mathrm{Nd}}$ terrace ends abruptly with a second, larger step decrease of $2.1 \varepsilon_{\mathrm{Nd}}$ at $33.75 \mathrm{Ma}$ that coincides with the second $\delta^{18} \mathrm{O}$ step. The nadir of the excursion is $-10.2 \varepsilon_{\mathrm{Nd}}$ at $33.7 \mathrm{Ma}$, which is followed by an $\sim 130$ k.y. recovery interval to higher values. The $\varepsilon_{\mathrm{Nd}}$ values in the postexcursion interval (33.633.3 Ma) average -8.0 .

The first significant occurrence of IRD appears $\sim 30 \mathrm{~cm}$ above the onset of the second step in $\delta^{18} \mathrm{O}$ and $\varepsilon_{\mathrm{Nd}}$ values, in a thin stratigraphic horizon ( $\sim 50 \mathrm{~cm}$ thick) (Fig. 2, right). IRD concentrations and mass accumulation rates reach peak values for $\sim 75$ k.y. centered ca. 33.7 Ma.

Individual fish teeth, including six samples from within the IRD horizon, show similar shale-normalized rare earth element and yttrium $(\mathrm{REE}+\mathrm{Y})$ profiles (Fig. 3). All of the patterns exhibit prominent cerium $(\mathrm{Ce})$ and $\mathrm{Y}$ anomalies, which are diagnostic features of seawater (German and Elderfield, 1990; Nozaki et al., 1997). Furthermore, samples in this study define a relationship of $\mathrm{Ce}$ versus $\mathrm{Y}$ anomalies that is inconsistent with mixing between oxic seawater and continental crust (see the Data Repository), making postburial uptake of IRD-derived REE + Y by fossil fish teeth unlikely.

\section{DISCUSSION}

\section{Timing of IRD Delivery to the Kerguelen Plateau}

The record of IRD accumulation at Site 738 indicates that grains were delivered to the Ker-

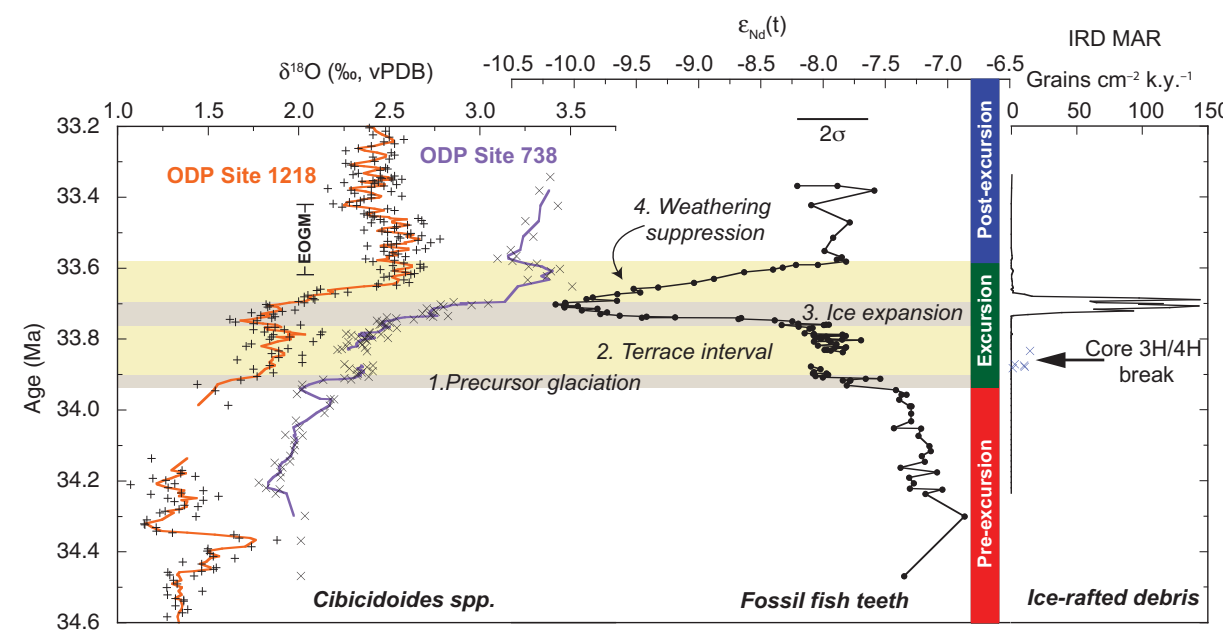

Figure 2. Ocean Drilling Program (ODP) Site $738 \delta^{18} \mathrm{O}, \mathrm{Nd}$ isotope, and ice-rafted debris (IRD) mass accumulation rates (MAR) records versus age. Vertical bar illustrates trends in $\varepsilon_{\mathrm{Nd}}$ record that define preexcursion (red), excursion (green), and postexcursion (blue) intervals. Four phases of ice sheet growth and/or weathering discussed in text are labeled. Anomalous IRD grains (marked by $\mathrm{X}$ ) that occur at the $738 \mathrm{~B}-3 \mathrm{H} / 4 \mathrm{H}$ core break are most likely due to contamination resulting from the coring process. Nd isotope results have been normalized

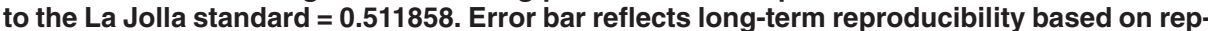
licate analysis of Ames Nd standard. Benthic foraminiferal $\delta^{18} \mathrm{O}$ record from ODP Site 1218 is from Coxall et al. (2005). All $\delta^{18} \mathrm{O}$ results have been adjusted by $+0.64 \%$. EOGM-earliest Oligocene glacial maximum.

${ }^{1}$ GSA Data Repository item 2011123, Tables DR1-DR5 and supplement; stable and radiogenic isotope, IRD, and REE data; and age model information, is available online at www.geosociety.org/pubs/ft2011.htm, or on request from editing@geosociety.org or Documents Secretary, GSA, P.O. Box 9140, Boulder, CO 80301, USA. guelen Plateau during a short episode of ice rafting ( $<75$ k.y.), consistent with earlier studies (Zachos et al., 1992). The coincidence of peak IRD accumulation with the second larger $\delta^{18} \mathrm{O}$ step indicates rapid, large-scale ice sheet expansion. However, no significant ice rafting was associated with the first $\delta^{18} \mathrm{O}$ step of the EOT or with the earliest Oligocene glacial maximum (EOGM; Liu et al., 2004).

\section{Nature of the Nd Isotope Excursion}

The Nd isotope excursion begins slightly before the onset of IRD deposition (ca. 33.7 Ma), a strong indication that both are related to a single process. Variations in bottom-water $\varepsilon_{\mathrm{Nd}}$ values reflect changes in water mass mixing and the weathering flux to the water mass source region. If late-stage diagenesis is not an issue, coherence between IRD and $\varepsilon_{\mathrm{Nd}}$ records can be interpreted in two ways. One is a shift in ocean circulation coincident with the expansion of ice sheets during the second step of the EOT. Alternatively, the $\mathrm{Nd}$ isotope excursion could reflect an increase in the dissolved weathering flux entering the source area of the water mass bathing the upper Kerguelen Plateau. Here we evaluate the likelihood of each of these interpretations.

The least radiogenic water mass during the EOT was in the North Atlantic $\left(\varepsilon_{\mathrm{Nd}}=-11\right.$; O'Nions et al., 1998). Northern Component Water (NCW) was exported into the South Atlantic and Southern Ocean during the Oligocene (Scher and Martin, 2008; Via and Thomas, 2006). However, mass balance indicates that the unlikely mixture of $78 \% \mathrm{NCW}$ at $\sim 63^{\circ} \mathrm{S}$ in the Indian sector of the Southern Ocean would have been required to produce the observed excursion. With the same parameters, $18 \%$ of NCW is required to produce the initial, smaller $\varepsilon_{\mathrm{Nd}}$

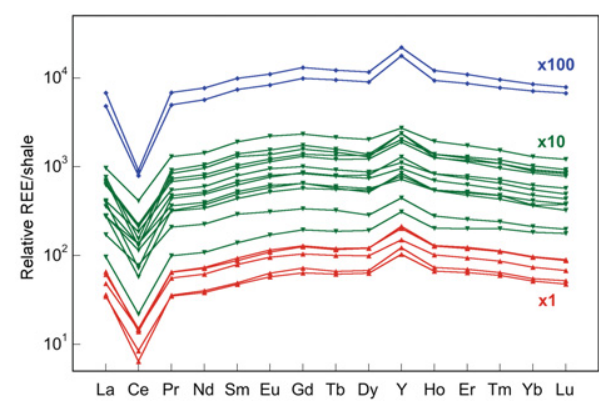

Figure 3. Shale-normalized rare earth element and yttrium (REE $+Y$ ) concentrations of fossil fish teeth used in this study normalized to post-Archean Australian Shale (PAAS) using values from Taylor and McLennan (1985). Normalized concentrations of samples taken from preexcursion (red), excursion (green), and postexcursion (blue) intervals have been adjusted by factors of 10 $(1,10$, and 100 , respectively) to enable visual comparison. Prominent $\mathrm{Ce}$ and $\mathrm{Y}$ anomalies are present in samples from each interval. 
step. However, $\varepsilon_{\mathrm{Nd}}$ values at $42^{\circ} \mathrm{S}$ in the southern Atlantic (ODP Site 1090; Scher and Martin, 2006) only shift by $0.6 \varepsilon_{\mathrm{Nd}}$ across the first $\delta^{18} \mathrm{O}$ step ( $251 \mathrm{~m}$ composite depth). Thus it is more likely that the source of nonradiogenic $\varepsilon_{\mathrm{Nd}}$ values during the first step was in closer proximity to the Kerguelen Plateau than to the Agulhas Ridge, which argues against an influx of NCW as the source of the excursion.

Mechanical erosion of Antarctic bedrock by ice sheets followed by rapid chemical breakdown of fresh mineral surfaces would have released extremely nonradiogenic $\mathrm{Nd}$ into the dissolved load accompanying the weathering surge during ice sheet growth. However, the delivery of $\mathrm{Nd}$ from Antarctic sources to bottom waters on the Kerguelen Plateau in pulses that are coeval with the benthic foraminiferal $\delta^{18} \mathrm{O}$ steps requires the combined operation of three transport vectors: (1) production of fine-grained material with freshly exposed mineral surfaces during ice sheet expansion, (2) rapid chemical breakdown of fresh surfaces during transport within the Prydz Bay drainage system, and (3) rapid mixing of dissolved nonradiogenic Nd from the Antarctic weathering flux with interior ocean water masses. The first and second transport processes are based on two tenets of glaciological theory: freshly exposed mineral surfaces undergo rapid chemical breakdown during transport (Anderson, 2007), and production of fine-grained sediment is as much as 10 times higher in glaciated catchments relative to nonglaciated ones (Hallet et al., 1996).

Operation of the third process is indicated by REE behavior in the modern ocean. REEs are scavenged in low-salinity regions of estuaries through colloidal flocculation and released in higher salinity regions (Sholkovitz, 1992, 1993), where they mix with shelf waters. Today, Antarctic Bottom Water (AABW) forms along the Antarctic shelf to the east of Prydz Bay (Orsi et al., 1999), and is detectable below $4000 \mathrm{~m}$ in the Australian-Antarctic basin (van de Flierdt et al., 2006). The Kerguelen Deep Western Boundary Current (DWBC) exports AABW at depths below $2500 \mathrm{~m}$ along the eastern flank of the plateau (Fukamachi et al., 2010). The paleodepth of the study site $(\sim 1750 \mathrm{~m})$ was $750 \mathrm{~m}$ shallower than the present-day depth of $\mathrm{AABW}$ in the DWBC; however, the $\varepsilon_{\mathrm{Nd}}$ signal may have migrated upward via mixing. Alternatively, the study site may have been influenced by local and/or regional production of an intermediate or deep-water mass on the Antarctic shelves.

\section{Weathering and Ice Volume History Across the EOT}

Our IRD and $\varepsilon_{\mathrm{Nd}}$ records enable a detailed reconstruction of continental weathering during early ice sheet expansion on East Antarctica. Changes in weathering during the excur- sion interval occurred in four phases (Fig. 2). During phase 1 , the flux of nonradiogenic Nd increased in conjunction with the first $\delta^{18} \mathrm{O}$ step, indicating that ice sheets formed at $33.9 \mathrm{Ma}$, here called the precursor glaciation. The $\varepsilon_{\mathrm{Nd}}$ signal in this interval resulted from the interplay of mechanical and chemical weathering, as described above, and is consistent with the initial appearance of illite-dominated clay mineral assemblages on the Kerguelen Plateau (ca. 33.9 Ma; Ehrmann and Mackensen, 1992), coincident with the first $\delta^{18} \mathrm{O}$ and $\varepsilon_{\mathrm{Nd}}$ steps. The early ice sheets were probably restricted to high interior elevations (e.g., DeConto and Pollard, 2003) and thus incapable of rafting icebergs, explaining the lack of IRD during the first $\delta^{18} \mathrm{O}$ and $\varepsilon_{\mathrm{Nd}}$ steps. A precursor glaciation that coincides with the first $\delta^{18} \mathrm{O}$ and $\varepsilon_{\mathrm{Nd}}$ step is compatible with recent estimates of changes in sea level across the first step (Katz et al., 2008).

Phase 2 is the terrace interval of relatively uniform $\varepsilon_{\mathrm{Nd}}$ values between the two steps. It is noteworthy that the duration of sustained negative $\varepsilon_{\mathrm{Nd}}$ values $(\sim 150$ k.y.) is much longer than the residence time of $\mathrm{Nd}$, requiring an ongoing flux of nonradiogenic Nd. This strongly indicates that the relatively stable small- to medium-sized ice sheets nonetheless advanced and retreated on orbital time scales, thus maintaining a supply of freshly weathered mineral surfaces for chemical weathering. This finding supports the ice sheet hysteresis hypothesis related to the height-mass balance feedback modeled by Pollard and DeConto (2005); i.e., once formed, high-elevation ice sheets are stable because the ice surface is above the zone of ablation, which is strongly controlled by atmospheric $\mathrm{CO}_{2}$ levels.

It is possible that Antarctic weathering during the terrace interval contributed to lower $\mathrm{CO}_{2}$ through two mechanisms. The first is nutrient delivery to the Southern Ocean supplied by enhanced weathering and vertical mixing (i.e., intensification of polar easterlies) and increased primary productivity, indicated by increased opal accumulation (Salamy and Zachos, 1999). Second, enhanced silicate weathering (Berner et al., 1983) in East Antarctica during this intermediate phase of limited glaciation may have acted as a positive feedback to cooling on EOT time scales (i.e., by increasing the silicate weathering $\mathrm{CO}_{2}$ sink). Estimates of surface ocean $\mathrm{pH}$ from Tanzanian drill cores suggest that $\mathrm{CO}_{2}$ was relatively low toward the end of the terrace interval (Pearson et al., 2009), supporting the argument that ice sheet weathering feedbacks helped sustain EOT climate change. Parallel changes between Antarctic weathering flux and calcite compensation depth deepening (e.g., Rea and Lyle, 2005) further indicate that weathering was an important factor for global carbon cycling in this interval.
During phase 3, a massive and abrupt increase in weathering flux occurred as the precursor ice sheets coalesced and expanded to cover the East Antarctic craton. Comparison of $\varepsilon_{\mathrm{Nd}}$ and IRD records shows that the dissolved weathering flux carried in proglacial rivers reached the sea slightly before IRD reached the Kerguelen Plateau. During phase 4, coinciding with the EOGM, rates of mechanical and chemical weathering slowed as temperatures dropped, liquid water became scarce, and weatherable area diminished. It is likely that these factors contributed to the termination of IRD deposition at the study site during the earliest Oligocene glacial maximum.

Over the recovery interval to higher $\varepsilon_{\mathrm{Nd}}$ values, the impact of chemical weathering on Antarctica as a sink for $\mathrm{CO}_{2}$ diminished, permitting $\mathrm{CO}_{2}$ to build up in the atmosphere (e.g., Pearson et al., 2009). Zachos and Kump (2005) modeled the climate response of decreasing Antarctic weatherability as a function of ice coverage and found that the $\mathrm{CO}_{2}$ response could explain the warming trend that ended the earliest Oligocene glacial maximum. Results from our study provide partial support of this hypothesis, demonstrating that a decrease in weathering accompanied the final build-up and maximum extent of the East Antarctic ice sheet during the Early Oligocene.

\section{CONCLUSIONS}

A detailed weathering history of East Antarctica during the EOT has been reconstructed on the basis of IRD MAR and $\varepsilon_{\mathrm{Nd}}$ values from fossil fish teeth at ODP Site 738 on the Kerguelen Plateau. These tracers of terrigenous input track two extremes in the size spectrum of glacially weathered products that reach the pelagic realm: mechanically weathered coarse grains transported by drifting icebergs and chemically weathered dissolved solutes transported by proglacial rivers. We show for the first time that two distinct weathering pulses occurred during the EOT, simultaneous with two benthic foraminiferal $\delta^{18} \mathrm{O}$ steps. Ice sheets formed in the latest Eocene (33.9 Ma) were limited to elevated regions and did not reach sea level, but persisted throughout the terrace interval until the second step. The large ice sheet that formed suddenly at 33.7 Ma quickly reduced the weatherable area on Antarctica, resulting in a weathering flux decline, with effects on the progression of global climate change during the Early Oligocene.

\section{ACKNOWLEDGMENTS}

We are grateful to Cedric John and two anonymous reviewers for careful reviews of this work. We thank Michael Lawrence for enlightening us to the nuances of Y anomalies and Clive Trueman for sharing the LuHf results from bioapatites and encouraging productive discourse about rare earth elements in bioapatites. National Science Foundation awards OCE-0647876 to Delaney and ANT-0732940 to Scher, as well as a 
University of California-Santa Cruz (UCSC) Institute of Marine Sciences Postdoctoral fellowship awarded to Scher, supported this project. Samples and data from the Ocean Drilling Program were used in this study. Work was carried out in the UCSC Marine Analytical Labs and WM Keck Radiogenic Isotope Facility. Rob Franks, Dan Sampson, and Jugdeep Aggarwal provided analytical and technical support.

\section{REFERENCES CITED}

Anderson, S.P., 2007, Biogeochemistry of glacial landscape systems: Annual Review of Earth and Planetary Sciences, v. 35, p. 375-399, doi: 10.1146/annurev.earth.35.031306.140033.

Armstrong, R.L., 1971, Glacial erosion and the variable isotopic composition of strontium in seawater: Nature, v. 230, p. 132-134.

Berner, R.A., Lasaga, A.C., and Garrels, R.M., 1983, The carbonate-silicate geochemical cycle and its effects on atmospheric carbon dioxide over the past 100 million years: American Journal of Science, v. 283 , p. $641-683$, doi: $10.2475 /$ ajs .283.7.641.

Cooper, A.K., and O'Brien, P.E., 2004, Leg 188 synthesis: Transitions in the glacial history of the Prydz Bay region, East Antarctica, from ODP drilling, in Cooper, A.K., et al., eds., Proceedings of the Ocean Drilling Program, Scientific results, Volume 188: College Station, Texas, Ocean Drilling Program, p. 1-42, http://wwwodp.tamu.edu/publications/188_SR/VOLUME/ SYNTH/SYNTH.PDF.

Coxall, H.K., Wilson, P.A., Pälike, H., Lear, C.H., and Backman, J., 2005, Rapid stepwise onset of Antarctic glaciation and deeper calcite compensation in the Pacific Ocean: Nature, v. 433, p. 53-57, doi: 10.1038/nature03135.

Dalai, T.K., Ravizza, G.E., and Peucker-Ehrenbrink, B., 2006, The Late Eocene ${ }^{187} \mathrm{Os} /{ }^{188} \mathrm{Os}$ excursion: Chemostratigraphy, cosmic dust flux and the Early Oligocene glaciation: Earth and Planetary Science Letters, v. 241, p. 477-492, doi: 10.1016/j.eps1.2005.11.035.

DeConto, R.M., and Pollard, D., 2003, Rapid Cenozoic glaciation of Antarctica induced by declining atmospheric $\mathrm{CO}_{2}$ : Nature, v. 421, p. 245249, doi: 10.1038/nature01290.

DePaolo, D.J., and Wasserburg, G.J., 1976, Nd isotopic variations and petrogenetic models: Geophysical Research Letters, v. 3, p. 249-252, doi: 10.1029/GL003i005p00249.

Ehrmann, W.U., and Mackensen, A., 1992, Sedimentological evidence for the formation of an East Antarctic ice sheet in Eocene/Oligocene time: Palaeogeography, Palaeoclimatology, Palaeoecology, v. 93, p. 85-112, doi: 10.1016/00310182(92) $90185-8$

Fitzsimons, I.C.W., 2003, Proterozoic basement provinces of southern and southwestern Australia, and their correlation with Antarctica, in Yoshida, M., et al., eds., Proterozoic East Gondwana: Supercontinent assembly and breakup: Geological Society of London Special Publication 206, p. 93-130 doi: 10.1144/GSL.SP.2003 .206.01.07.

Fukamachi, Y., Rintoul, S.R., Church, J.A., Aoki, S., Sokolov, S., Rosenberg, M.A., and Wakatsuchi, M., 2010, Strong export of Antarctic Bottom Water east of the Kerguelen plateau: Nature Geoscience, v. 3, p. 327-331, doi: 10.1038/ngeo842.

German, C.R., and Elderfield, H., 1990, Application of the Ce anomaly as a paleoredox indicator: The ground rules: Paleoceanography, v. 5, p. 823-833, doi: 10.1029/PA005i005p00823. erosion and sediment evacuation by glaciers: A review of field data and their implications: Global and Planetary Change, v. 12, p. 213 235, doi: 10.1016/0921-8181(95)00021-6.

Katz, M.E., Miller, K.G., Wright, J.D., Wade, B.S., Browning, J.V., Cramer, B.S., and Rosenthal, Y., 2008, Stepwise transition from the Eocene greenhouse to the Oligocene icehouse: Nature Geoscience, v. 1, p. 329-334, doi: 10.1038ngeo179.

Kocsis, L., Trueman, C.N., and Palmer, M.R., 2010, Protracted diagenetic alteration of REE contents in fossil bioapatites: Direct evidence from Lu-Hf isotope systematics: Geochimica et Cosmochimica Acta, v. 74, p. 6077-6092, doi: 10.1016/j.gca.2010.08.007.

Liu, Z.F., Tuo, S.T., Zhao, Q.H., Cheng, X.R., and Huang, W., 2004, Deep-water earliest Oligocene glacial maximum (EOGM) in South Atlantic: Chinese Science Bulletin, v. 49, p. 2190-2197, doi: 10.1360/04wd0228

Martin, E.E., and Haley, B.A., 2000, Fossil fish teeth as proxies for seawater $\mathrm{Sr}$ and $\mathrm{Nd}$ isotopes: $\mathrm{Geo}$ chimica et Cosmochimica Acta, v. 64, p. 835847, doi: 10.1016/S0016-7037(99)00376-2.

Nozaki, Y., Zhang, J., and Amakawa, H., 1997, The fractionation between $\mathrm{Y}$ and $\mathrm{Ho}$ in the marine environment: Earth and Planetary Science Letters, v. 148 , p. $329-340$, doi: $10.1016 /$ S0012 $-821 X(97) 00034-4$

O’Nions, R.K., Frank, M., von Blanckenburg, F., and Ling, H.F., 1998, Secular variation of Nd and $\mathrm{Pb}$ isotopes in ferromanganese crusts from the Atlantic, Indian and Pacific Oceans: Earth and Planetary Science Letters, v. 155, p. 15-28, doi: 10.1016/S0012-821X(97)00207-0.

Orsi, A.H., Johnson, G.C., and Bullister, J.L., 1999, Circulation, mixing, and production of Antarctic Bottom Water: Progress in Oceanography, v. 43, p. 55-109, doi: 10.1016/S0079 -6611(99)00004-X.

Pearson, P.N., Foster, G.L., and Wade, B.S., 2009, Atmospheric carbon dioxide through the EoceneOligocene climate transition: Nature, v. 461, p. 1110-1113, doi: 10.1038/nature08447.

Pollard, D., and DeConto, R.M., 2005, Hysteresis in Cenozoic Antarctic ice-sheet variations: Global and Planetary Change, v. 45, p. 9-21, doi: 10.1016/j.gloplacha.2004.09.011.

Rea, D.K., and Lyle, M.W., 2005, Paleogene calcite compensation depth in the eastern subtropical Pacific: Answers and questions: $\mathrm{Pa}-$ leoceanography, v. 20, PA1012, doi: 10.1029/ 2004PA001064.

Roy, M., van de Flierdt, T., Hemming, S.R., and Goldstein, S.L., $2007,{ }^{40} \mathrm{Ar} /{ }^{39} \mathrm{Ar}$ ages of hornblende grains and bulk $\mathrm{Sm} / \mathrm{Nd}$ isotopes of circum-Antarctic glacio-marine sediments: Implications for sediment provenance in the Southern Ocean: Chemical Geology, p. 507519, doi: 10.1016/j.chemgeo.2007.07.017.

Salamy, K.A., and Zachos, J.C., 1999, Latest EoceneEarly Oligocene climate change and Southern Ocean fertility: Inferences from sediment accumulation and stable isotope data: Palaeogeography, Palaeoclimatology, Palaeoecology, v. 145 p. 61-77, doi: 10.1016/S0031-0182(98)00093-5.

Scher, H.D., and Martin, E.E., 2004, Circulation in the Southern Ocean during the Paleogene inferred from neodymium isotopes: Earth and Planetary Science Letters, v. 228, p. 391-405, doi: 10.1016/j.epsl.2004.10.016.

Scher, H.D., and Martin, E.E., 2006, Timing and climatic consequences of the opening of Drake
Passage: Science, v. 312, p. 428-430, doi: 10.1126/science. 1120044

Scher, H.D., and Martin, E.E., 2008, Oligocene deep water export from the North Atlantic and the development of the Antarctic Circumpolar Current examined with neodymium isotopes: Paleoceangraphy, v. 23, PA1205, doi: 10.1029/2006PA001400

Sholkovitz, E.R., 1992, Chemical evolution of rareearth elements-Fractionation between colloidal and solution phases of filtered river water: Earth and Planetary Science Letters, v. 114, p. 77-84, doi: 10.1016/0012-821X(92)90152-L.

Sholkovitz, E.R., 1993, The geochemistry of rare earth elements in the Amazon River estuary: Geochimica et Cosmochimica Acta, v. 57, p. $2181-2190$, doi: $10.1016 / 0016-7037$ (93) $90559-\mathrm{F}$

Staudigel, H., Doyle, P., and Zindler, A., 1985, Sr and $\mathrm{Nd}$ isotope systematics in fish teeth: Earth and Planetary Science Letters, v. 76, p. 45-56, doi: 10.1016/0012-821X(85)90147-5.

Taylor, S.R., and McLennan, S.M., 1985, The continental crust: Its composition and evolution: Oxford, UK, Blackwell Scientific Publications, $312 \mathrm{p}$.

van de Flierdt, T., Hemming, S.R., Goldstein, S.L., and Abouchami, W., 2006, Radiogenic isotope fingerprint of Wilkes Land-Adélie Coast Bottom Water in the circum-Antarctic Ocean: Geophysical Research Letters, v. 33, L12606, doi: 10.1029/2006GL026020.

van de Flierdt, T., Goldstein, S.L., Hemming, S.R., Roy, M., Frank, M., and Halliday, A.N., 2007, Global neodymium-hafnium isotope systematics-Revisited: Earth and Planetary Science Letters, v. 259, p. 432-441, doi: 10.1016/j.epsl 2007.05.003.

van de Flierdt, T., Hemming, S.R., Goldstein, S.L., Gehrels, G.E., and Cox, S.E., 2008, Evidence against a young volcanic origin of the Gamburtsev Subglacial Mountains, Antarctica: Geophysical Research Letters, v. 35, L21303, doi: 10.1029/2008GL035564.

Via, R.K., and Thomas, D.J., 2006, Evolution of Atlantic thermohaline circulation: Early Oligocene onset of deep-water production in the North Atlantic: Geology, v. 34, p. 441-444, doi: 10.1130/G22545.1.

Zachos, J.C., and Kump, L.R., 2005, Carbon cycle feedbacks and the initiation of Antarctic glaciation in the earliest Oligocene: Global and Planetary Change, v. 47, p. 51-66, doi: 10.1016/j .gloplacha.2005.01.001.

Zachos, J.C., Breza, J., and Wise, S.W., 1992, Early Oligocene ice-sheet expansion on Antarctica: Stable isotope and sedimentological evidence from Kerguelen Plateau, southern Indian Ocean: Geology, v. 20, p. 569-573, doi: 10.1130/0091-7613(1992)020<0569:EOISEO $>2.3 . \mathrm{CO} ; 2$.

Zachos, J.C., Opdyke, B.N., Quinn, T.M., Jones, C.E., and Halliday, A.N., 1999, Early Cenozoic glaciation, Antarctic weathering, and seawater ${ }^{87} \mathrm{Sr} r{ }^{86} \mathrm{Sr}$ : Is there a link?: Chemical Geology, v. 161 , p. $165-180$, doi: 10.1016/S0009 -2541(99)00085-6.

Manuscript received 7 September 2010

Revised manuscript received 18 November 2010 Manuscript accepted 22 November 2010

Printed in USA 